\title{
Article
}

\section{Non-destructive assessment of the oxidative stability of intact macadamia nuts during the drying process by near- infrared spectroscopy}

Carvalho, Livia C., Leite, Marcondes L., Medeiros-De-morais, Camilo De lelis, Lima, Kassio M.G. and Teixeira, Gustavo H.A.

Available at http://clok.uclan.ac.uk/26397/

Carvalho, Livia C., Leite, Marcondes L., Medeiros-De-morais, Camilo De lelis ORCID: 0000-0003-2573-787X, Lima, Kassio M.G. and Teixeira, Gustavo H.A. (2019) Non-destructive assessment of the oxidative stability of intact macadamia nuts during the drying process by near-infrared spectroscopy. LWT - Food Science and Technology, 103 . pp. 101-107. ISSN 0023-6438

It is advisable to refer to the publisher's version if you intend to cite from the work. http://dx.doi.org/10.1016/j.lwt.2018.12.056

For more information about UCLan's research in this area go to http://www.uclan.ac.uk/researchgroups/ and search for <name of research Group>.

For information about Research generally at UCLan please go to http://www.uclan.ac.uk/research/

All outputs in CLoK are protected by Intellectual Property Rights law, including Copyright law. Copyright, IPR and Moral Rights for the works on this site are retained by the individual authors and/or other copyright owners. Terms and conditions for use of this material are defined in the policies page. 
1 Non-destructive assessment of the oxidative stability of intact macadamia nuts during the

4 Lívia C. Carvalho ${ }^{1}$, Marcondes L. Leite ${ }^{2,4}$, Camilo L. M. Morais ${ }^{3}$, Kássio M. G. Lima ${ }^{4}$, Gustavo H. $5 \quad$ A. Teixeira ${ }^{5, *}$

$7{ }^{1}$ Universidade Estadual Paulista (UNESP), Faculdade de Ciências Farmacêuticas (FCFAR), 8 Departamento de Alimentos e Nutrição, Campus de Araraquara, Rodovia Araraquara-Jaú, km 1 - CP 9 502, CEP: 14.800-903, Araraquara, São Paulo, Brazil.

$10{ }^{2}$ Instituto Federal de Educação, Ciência e Tecnologia do Maranhão (IFMA), Campus São Luís11 Maracanã. Avenida dos Curiós, s/n, Vila Esperança, CEP: 65.095-460, São Luís, Maranhão, Brazil.

$12{ }^{3}$ University of Central Lancashire, School of Pharmacy and Biomedical Sciences, Preston, 13 Lancashire, PR1 2HE, United Kingdom.

$14{ }^{4}$ Universidade Federal do Rio Grande do Norte (UFRN), Instituto de Química, Química Biológica e 15 Quimiometria, Avenida Senador Salgado Filho, $\mathrm{n}^{\circ}$ 3000, Bairro de Lagoa Nova, CEP: 59.078-970, 16 Natal, Rio Grande do Norte, Brazil.

$17{ }^{5}$ Universidade Estadual Paulista (UNESP), Faculdade de Ciências Agrárias e Veterinárias (FCAV), 18 Campus de Jaboticabal. Via de Acesso Prof. Paulo Donato Castellane s/n, CEP: 14.884-900, 19 Jaboticabal, São Paulo, Brazil. Telephone: +55 16 3209-7532

20 *Corresponding author: gustavo@fcav.unesp.br 


\section{Abstract}

We have developed a rapid non-destructive method to assess the oxidative stability of intact macadamia nuts using near-infrared spectroscopy (NIRS). Intact macadamia nuts of the cultivars HAES 344 'Kau', HAES 660 'Keaau', IAC 4-12 B, and IAC Campinas B were harvested and immediately oven-dried for 4 days at $30{ }^{\circ} \mathrm{C}, 2$ days at $40{ }^{\circ} \mathrm{C}$, and 1 day at $60{ }^{\circ} \mathrm{C}$ to achieve $1.5 \%$ kernel moisture content. At each drying step nuts were withdrawn and their moisture content, peroxide value (PV), and acidity index (AI) determined. The best partial least square model for PV prediction was obtained using the Savitzky-Golay (SG) second derivative resulting in a standard error of prediction (SEP) of $0.55 \mathrm{meq} \cdot \mathrm{kg}^{-1}$ and a coefficient of determination $\left(\mathrm{R}^{2} \mathrm{C}\right)$ of 0.57 . The best AI prediction-model result was obtained using the $\mathrm{SG}$ second derivative $\left(\mathrm{SEP}=0.14 \%, \mathrm{R}^{2} \mathrm{C}=0.29\right)$. Based on the maximum quality limits of $3 \mathrm{meq} \cdot \mathrm{kg}^{-1}$ for PV and $0.5 \%$ for AI, the SEP values represented $18 \%$ and $28 \%$, respectively. Therefore, the prediction method can be considered useful since the errors are lower than the quality limits. Thus, NIRS can be used to assess the oxidative stability of intact macadamia kernels.

38 Keywords: peroxide value, acidity index, Macadamia integrifolia Maiden \& Betche, principal component analysis.

\section{Introduction}


predominantly monounsaturated fatty acids, while only around $16 \%$ are saturated fatty acids (Wood and Garg, 2010). This composition plays an important role in their quality, particularly in the organoleptic properties that make macadamia nuts so desirable (Silva, Maximo, Marsaioli Jr. \& Silva, 2007).

Due to their high oil content, macadamia nuts are very susceptible to the occurrence of rancidification in the kernels, which causes objectionable flavors and odors in food products (Ramalho \& Jorge, 2006; Silva et al., 2011). In addition, macadamia nuts contain the low levels of tocopherol antioxidants $\left(\sim 0.6-2.8 \mu \mathrm{g} \cdot \mathrm{g}^{-1}\right),($ Wall, 2013). retard rancidification and extend shelf-life, shelled nuts should be protected from moisture and oxygen during storage (Wall, 2013). Since the oxidative stability of the kernels is related to their moisture content, this parameter must be monitored to ensure drying to below $1.5 \%$ (Cavaletto, 1981; Silva et al., 2005; Borompichaichartkul et al., 2009). At this moisture level the water activity (aw) is equal or less than 0.3 , which represents the optimum point for oxidative stability of dehydrated foods (Cavaletto, 1981; Wall, 2013). In addition to this, the maximum stability of macadamia nut corresponds to the minimum integral entropy zone (Dominguez et al., 2007), which corresponds to a range of aw from 0.36 to 0.44 (1.2-1.6\% moisture). Therefore, $1.5 \%$ moisture content is fundamental to assure the oxidative stability of macadamia nuts.

Since freshly harvested nuts have a moisture content higher than 30\% (Pankaew et al., 2016), drying should be started soon after harvesting to reduce the moisture content to prevent hydrolytic rancidity due to the nuts' high oil content (Mason and Wills, 2000) and/or mold development, such as Colletotrichum gloeosporioides and Botrytis sp. (Dierberger and Marino Netto, 1985).

The most useful analytical parameters to determine the degree of oxidation are peroxide value (PV) and acidity index (AI) (Wolff, 1997). PV is related to the formation of peroxides in unsaturated fats, due to the breaking of the double bonds, which generates short-chain volatile products 
71 responsible for rancid odors. AI is related to the acidification of fats due to enzymatic reactions,

72 generating free fatty acids that could have unpleasant taste (Wolff, 1997). PV and AI can change at

73 high temperatures and can also depend on the cultivars. For example, PV changes on heating as it

74 decomposes into highly unstable secondary oxidation products while AI is influenced by heating due

75 to the reduced kernel-water content and/or altered enzymatic activity (Bai et al., 2017).

AI and PV must comply with the quality standards established for cold-pressed and non-

77 refined macadamia oils which require a maximum $\mathrm{PV}$ value of $3.5 \mathrm{meq} \cdot \mathrm{kg}^{-1}$ and a maximum AI

value of $0.5 \%$ (SAMAC, 2015). The standard methods for PV and AI analyses are slow and time-

consuming, requiring precise quantification of the sample, dissolution in solvents, and titration with

standardized solutions, and are also relatively costly when used for industrial process monitoring

81 (Cozzolino, Murray, Chree \& Scaife, 2005).

Near-infrared spectroscopy (NIRS) is widely employed for oxidation and moisture content

determination in oilseeds and grains and has the potential to become a powerful tool in lipid oxidation analysis, especially with chemometric statistical evaluations. Non-destructive techniques have great potential for shelled- and unshelled- macadamia nut sorting, and NIRS is such an alternative, due to its long-term application to assess food-product quality parameters (Osborne, Fearn \& Hindle, 1993).

Canneddu, Júnior \& Teixeira (2016) used FT-NIR spectroscopy without any pre-processing to study the quality of shelled- and unshelled macadamia nuts, obtaining a coefficient of 90 determination $\left(\mathrm{R}_{\mathrm{p}}^{2}\right)$ of 0.72 for $\mathrm{PV}$ prediction and an $\mathrm{R}_{\mathrm{p}}^{2}$ of 0.80 for AI prediction. Guthrie, Greensill, 91 Bowden \& Walsh (2005), evaluated the use of NIRS to assess the quality of macadamia kernels and 92 found an acceptable oil content prediction (root mean square error of cross validation $\mathrm{RMSE}_{\mathrm{CV}}=$ $932.5 \%$ and $\left.\mathrm{R}^{2}>0.98\right)$, and moisture content prediction $\left(\mathrm{RMSE}_{\mathrm{CV}}<0.2 \%\right.$, and $\left.\mathrm{R}^{2}>0.97\right)$. 
As NIRS is a fast and non-destructive method used in industrial quality control processes, the

objective of this study was to evaluate its feasibility as an analytical method to improve the quality control of macadamia-nuts in post-harvest operations.

\section{Materials and Methods}

\subsection{Plant Material}

Twelve kilograms $(\mathrm{kg})$ of intact dehusked macadamia (Macadamia integrifolia Maiden \& 101

Initially (day 0) and at each drying step (4, 6, and 7 days), intact nuts (40 g) were withdrawn from the oven and the shell manually removed using a vice (N3, Schulz, Brazil). Unshelled nuts had their moisture content (\%) determined following the A.O.A.C. (1997) standard method, Table 2.

Our experiment was set up as a completely randomized block design in a factorial arrangement 3 (harvests: March, April, and May) x 4 (cultivars: HAES 344 'Kau', HAES 660 'Keaau', IAC 4-12 B, and IAC Campinas B) $\times 3$ (drying steps: 0 - control, 4 days at $30{ }^{\circ} \mathrm{C}, 2$ more days at $40{ }^{\circ} \mathrm{C}$, and 1 more day at $60{ }^{\circ} \mathrm{C}$ ) with 5 repetitions, totaling 240 unshelled nut samples. 


\subsection{NIR spectra acquisition}

The NIR spectra were taken on day $0,4,6$, and 7 of the drying steps, on the surface of $\sim 40$ grams of unshelled macadamia nuts from each cultivar. The nuts were place into a measuring cup and two NIR spectra were obtained on the range $866-2,530 \mathrm{~nm}$, at a resolution of $2 \mathrm{~nm}$ and 64 scans, after temperature stabilization at $\sim 25{ }^{\circ} \mathrm{C}$, using a Bruker NIR spectrometer (Model Tango, Ettlingen, Germany) in reflectance mode. The NIR spectra were averaged, and the mean spectra were processed, and the calibration models were performed using the MATLAB $\AA$, R2012b (MathWorks, USA) software.

\subsection{Reference analyses: PV and AI}

After drying, all samples were frozen at $-20{ }^{\circ} \mathrm{C}$, stored into plastic bags ( $40 \mathrm{~g}$ of nuts per period and cultivar), to avoid oxidation. The oil present in the nuts were extracted daily to avoid supplementary oxidation, using the procedure reported by Canneddu, Júnior \& Teixeira (2016). Briefly, the kernels were wrapped in nylon fabric and put into a stainless-steel vial with a tightly adjusted stainless-steel piston. The piston was pressed until free oil could be seen. The oil was rapidly transferred to a Falcon tube (BD Falcon ${ }^{\mathrm{TM}}$, BD Biosciences, Mass., USA) and used for the oxidation analysis.

$P V$ : The peroxide value was determined using the official method published by the A.O.A.C. (1997). Briefly, $5 \mathrm{~g}$ of freshly pressed macadamia oil was poured into a $125 \mathrm{~mL}$ Erlenmeyer. Thirty $\mathrm{mL}$ of acetic acid-chloroform solution $(3: 2 \mathrm{v} / \mathrm{v})$ was added and the flask was agitated until oil dissolution. Then, $0.5 \mathrm{~mL}$ of saturate potassium iodide solution was added, mixed, and let to rest for 1 minute. Thirty $\mathrm{mL}$ of distilled water was added, and the solution titrated with $0.01 \mathrm{~N}$ sodium thiosulfate. PV was expressed as active-oxygen milliequivalents per kilogram $\left(\mathrm{meq} \cdot \mathrm{kg}^{-1}\right)$. The descriptive statistics of all samples is shown in Table 1.

AI: The acidity index was also determined using the A.O.A.C. (1997) official method. Five $\mathrm{mL}$ of freshly pressed macadamia oil was poured into a $125 \mathrm{~mL}$ Erlenmeyer and $25 \mathrm{~mL}$ of ether- 
ethanol $(2: 1 \mathrm{v} / \mathrm{v})$ solution was added. $\mathrm{NaOH} 0.01 \mathrm{M}$ was used to neutralize the free fatty acids present in the oil with phenolphthalein $(0.1 \%)$ as indicator. AI was expressed as the percentage of oleic acid (\%). The descriptive statistics of all samples are shown in Table 1.

\subsection{Data analysis}

\subsubsection{Chemometrics: multivariate analysis}

All the NIR spectra were handled, and the calibration models developed, using the MATLAB®, R2012b (MathWorks, USA) software with the PLS Toolbox version 7.9.3 (Eigenvector Research, Inc., USA). Prior to the spectral pre-processing, all NIR spectra were analyzed to identify and eliminate outliers based on Hotelling's $\mathrm{T}^{2}$ and Q-residuals statistics (Bro and Smilde, 2014).

NIR datasets are often very large and highly complex and, consequently, need to be preprocessed. Therefore, prior to model development, the full spectra were pre-processed using multiplicative scatter correction (MSC), standard normal variate (SNV), Savitzky-Golay smoothing (SG), and derivatives. Then, the spectral datasets were correlated with the PV and AI values using Partial Least Squares (PLS) regression and full cross-validation. The NIR spectra were divided into two groups: the calibration set $(n=154)$ and the validation set $(n=66)$, using the classic KernnardStone selection algorithm (Kennard and Stone, 1969). In order to evaluate the performance of the calibration models, the root mean square error of cross-validation $\left(\mathrm{RMSE}_{\mathrm{CV}}\right)$ and root mean square error of prediction (RMSEP) were calculated, according to the following equation:

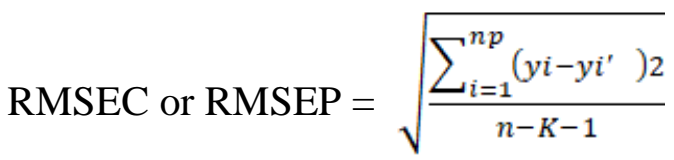

Where: $y i$ is the value predicted by the multivariate model, $y i$ ' the reference value, and $n$ the number of samples.

The performance of the calibration models was also evaluated based on the determination coefficient $\mathrm{R}^{2}$, both for the calibration and validation sets (Pasquini, 2003). 

Maldonado Júnior, 2015) software and the means were compared using Tukey's test with 5\% probability.

171 3. Results and Discussion

\subsection{Nut quality during drying}

The moisture, dry matter contents (\%), PV and AI of the unshelled macadamia nuts of the 174 different cultivars, determined during drying, are shown in Table 2.

No significant moisture content differences were observed between nuts from different cultivars, but during the drying process moisture content became significantly lower (Table 2). The moisture content between cultivars ranged from 5.97\% in HAES 344 to $7.24 \%$ in IAC Campinas B.

During the drying process the highest moisture content was observed on day $0(13.81 \%)$; after 4 days at $30{ }^{\circ} \mathrm{C}$ this value significantly $(\mathrm{P}<0.05)$ decreased to $6.09 \%$. The moisture content decreased to $4.13 \%$ after 2 days at $40{ }^{\circ} \mathrm{C}$, and to $2.62 \%$ after 1 day at $60{ }^{\circ} \mathrm{C}$, but without significant differences.

The dry matter content showed a similar trend, but in the opposite direction, increasing during drying due to the dehydration process (Table 2).

According to Mason (2000) and Cavaletto (1983), macadamia nuts at harvest can have a deterioration, mainly to control mold development, rancidity, off-flavors, and reduced shelf-life. In this regard, only the nuts from day 0 presented a moisture content above this range, and after only 4 days at $30{ }^{\circ} \mathrm{C}$ the moisture content reached $6.09 \%$, inside the $8-10 \%$ range.

The moisture content control during macadamia nut handling is extremely important as rancidity can occur rapidly (Cavaletto, 1981; Cavaletto, 1986; Wall, 2013). According to Kaijser, 
Dutta \& Savage (2000), macadamia oil stability ranged from 3.6 to $19.8 \mathrm{~h}$ using the Rancimat test.

193

Macadamia nuts are susceptible to rancidification due to their high oil content. Cavaletto (1983) reported an oil content of $72 \%$ and Kaijser, Dutta \& Savage (2000) observed a range from 69 to 78\%. In addition, the macadamia oil is highly monounsaturated (Ako, Okoda \& Gray, 1995) and contains high levels of oleic (18:1), palmitoleic (16:1), and palmitic (16:0) acids (Kaijser, Dutta \& Savage, 2000). Therefore, because drying was conducted immediately after harvest it resulted in a rapid moisture content reduction that improved the oxidative stability of the kernel, as evidenced by the low PV and AI values (Table 2).

No significant PV differences were observed neither from different cultivars nor during the drying process (Table 2). PV ranged from $1.08 \mathrm{meq} \cdot \mathrm{kg}^{-1}$ in the nuts from the IAC $4-12$ cultivar to $0.73 \mathrm{meq} \cdot \mathrm{kg}^{-1}$ in those from HAES 344 (Table 2). During drying the PV ranged from 1.27 in day 0 to $0.66 \mathrm{meq} \cdot \mathrm{kg}^{-1}$ after 4 days at $30{ }^{\circ} \mathrm{C}, 2$ days at $40{ }^{\circ} \mathrm{C}$, and 1 day at $60{ }^{\circ} \mathrm{C}$ (Table 2). The observed PVs were very low compared to those of the macadamia quality standards. According to Mason, Nottingham, Reid \& Gathambiri (2004) the AMS Guidelines indicate a maximum PV of 5.0 meq $\cdot \mathrm{kg}^{-1}$ for oil from raw and roasted macadamia kernels. According to SAMAC (2015), raw macadamia nuts must have PV less than $3.5 \mathrm{meq} \cdot \mathrm{kg}^{-1}$. Macadamia oil is considered moderately to completely rancid when its PV reaches $6.0 \mathrm{meq} \cdot \mathrm{kg}^{-1}$ (McConachie, 1996).

PV can be influenced by the cultivar as each cultivar has a different nut polyunsaturated fatty acid composition (Kaijser, Dutta \& Savage, 2000). Processing also influences PV. Canneddu, Júnior \& Teixeira (2016), reported lower PVs $\left(5.6-5.5 \mathrm{meq} \cdot \mathrm{kg}^{-1}\right)$ in freshly harvested intact and ground macadamia nuts, when compared to half kernels from late harvest $\left(10.7-18.8 \mathrm{meq} \cdot \mathrm{kg}^{-1}\right)$. Oxidative rancidity is very important in lipid stability and since macadamia nuts have a low concentration of polyunsaturated fatty acids $(3.0-4.7 \%)$ peroxides production is generally low in unstored kernels (Kaijser, Dutta \& Savage, 2000). However, it can be a quality problem during drying 
216 (Borompichaichartkul, Luengsode, Chinprahast \& Devahastin, 2009) and long-term storage 217 (Sinanoglou et al., 2014).

Regarding AI, no significant $(\mathrm{P}>0.05)$ differences between different cultivars were observed 219 and during drying process the AI decreases significantly (Table 2 ) ranging from $0.75 \%$ in nuts from 220 the IAC Campinas B cultivar to $0.66 \%$ in those from HAES 344 . During the drying process the 221 highest AI was observed at day $0(1.0 \%)$; after 4 days at $30{ }^{\circ} \mathrm{C}$ this value significantly $(\mathrm{P}<0.05)$ 222 decreased to $0.63 \%$. AI decreased to $0.61 \%$ after 2 days at $40{ }^{\circ} \mathrm{C}$ and to $0.56 \%$ after 1 day at $60{ }^{\circ} \mathrm{C}$, 223 but without significant differences (Table 2). This reduction of AI during the drying process could be 224 related to the inactivation of the enzymes involved in the hydrolytic reactions (Silva et al., 2011), 225 which are directly related to the moisture content present in the kernel (Silva, Maximo, Marsaioli 226 Júnior \& Silva, 2007). Although the drying process was conducted immediately after harvesting, AI 227 values were above the maximum levels recommended for macadamia oil.

According to SAMAC (2015), the maximum AI should be 0.5\%. McConachie (1996) considered that high quality macadamia oil should have AI of only $0.1-0.3 \%$, but Arnett (1995) considered an AI of $0.9 \%$ as acceptable. Therefore, hydrolytic rancidity seems to be a more important factor for macadamia nuts quality, as its development of rancid flavors and odors can take place rapidly even during prompt drying.

\subsection{NIR spectra description}

A preliminary analysis of the raw NIR spectra showed very similar trends for the macadamia nuts from all cultivars. Carvalho et al. (2018) also observed similarities of different macadamia nut 237 NIR spectra and the classification of shelled nuts was only possible using sophisticate chemometric techniques. Because the raw NIR spectra presented broad light scattering they were pre-processed with MSC and SNV plus Savitsky-Golay smoothing to allow the identification of four main peaks at 1200, 1500, 1800, and $2000 \mathrm{~nm}$. The absorption bands around $1200 \mathrm{~nm}$ arise from the second 
241 overtones of $\mathrm{CH}$ stretching vibrations, while those at 1700-1800 nm are attributable to the first overtones of $\mathrm{CH}$ stretching vibrations of $-\mathrm{CH}_{3},-\mathrm{CH}_{2}-$ and $-\mathrm{HC}=\mathrm{CH}$ (Armenta and La Guardia, 2007). The wavelength region situated at $2200-2500 \mathrm{~nm}$ is mainly related to the oxidation and

hydrolytic degradation of lipids (Cozzolino, Murray, Chree \& Scaife, 2005).

During the drying process the NIR spectra changed mainly in the regions where the water bands are present (1400-1440 nm and 1900-1950 nm) (Sundaram, Kandala, Holser, Butts \& Windham, 2010), indicating that there was a reduction in moisture content, as can be seen in Table 2. Principal component analysis (PCA) was used to observe the spectral differences between drying processes and macadamia nut cultivars, helping to observe possible groupings between the samples due to their similarities (Cozzolino, Cynkar, Shah \& Smith, 2011). The scores of the two main principal components (PCs) obtained with the NIR spectra without preprocessing can be observed in Figure 1. Regarding the drying process, PC2 grouped the macadamia nut NIR spectra from day 0 and 7 (Figure 1A), as there was a significant moisture content difference $(\mathrm{P}<0.05)$ between day 0 and day 7 (Table 2). It was not possible to observe any grouping among macadamia nut cultivars (Figure 1B), with PC1 and PC2 representing 97\% of the data explained variance. This result indicates that there was similarity between macadamia nut cultivars, which may be related to climatic factors and/or for sharing the same pollination since they originated from the same orchard (Carvalho et al. 2018).

\subsection{Oxidative stability: PV and AI}

The PV of the samples ranged from 0.14 to $5.41 \mathrm{meq} \cdot \mathrm{kg}^{-1}$ and the AI from 0.18 to $2.26 \%$ (Table 1) in the calibration set. As shown in Table 3, the best PLS model for PV $\left(\mathrm{RMSE}_{\mathrm{C}}=0.56\right.$ meq. $\mathrm{kg}^{-1}, \mathrm{R}_{\mathrm{c}}^{2}=0.57$, SEP $=0.55$ meq. $\mathrm{kg}^{-1}, \mathrm{RMSE}=0.60$ meq. $\mathrm{kg}^{-1}, \mathrm{R}_{\mathrm{P}}^{2}=0.002$ ) was obtained when the NIR spectra were pre-processed with SG second derivative. The predicted vs. measured PV values can also be seen in Figure 2. Canneddu, Júnior \& Teixeira (2016) studying the quality of 
unshelled macadamia nuts by NIRS found higher SEP values $\left(3.45 \mathrm{meq} \cdot \mathrm{kg}^{-1}\right)$, but with a greater variation in the PV values $\left(4.6-26.8 \mathrm{meq} \cdot \mathrm{kg}^{-1}\right)$ of the calibration set. Better PV prediction by NIRS was reported by Armenta and La Guardia (2007) in edible oils of different types and origins, with $\mathrm{RMSE}_{\mathrm{p}}$ values of $1.87 \mathrm{meq} \cdot \mathrm{kg}^{-1}$ and $\mathrm{R}_{\mathrm{c}}{ }_{\mathrm{c}}$ of 0.99 . However, intact macadamia nuts are a more heterogeneous matrix as compared to vegetable oils and this could have affected the results, especially the lower determination coefficients (Table 3).

In contrast, considering the maximum PV quality limit of $3.0 \mathrm{meq} \cdot \mathrm{kg}^{-1}$ (SAMAC, 2015), the SEP value $\left(0.55 \mathrm{meq} \cdot \mathrm{kg}^{-1}\right)$ represented $18 \%$ of this recommendation. Therefore, the PV prediction method can be considered excellent as its total error was of magnitude $25 \%$ or less (McFarren, Lishka \& Parker, 1970).

Regarding AI, the best PLS model was obtained when the NIR spectra were pre-processed with 7 latent variables), Table 3 and Figure 3 . As indicated in Table 3, the SEP and RMSE differences were not significant which could be taken as an indication that the prediction precision of the PLS regression was high (Amodio, Ceglia, Chaudhrya, Piazzolla \& Colellia, 2017), although $\mathrm{R}^{2}$ was low. Similar RMSEp values $(0.35 \%)$ were reported by Mba, Adewale, Dumont \& Ngadi (2014) in palm and canola oils with NIR spectra pre-processed using SG first derivative, but their $\mathrm{R}^{2}$ was much greater (0.99). Better results were reported by Armenta and La Guardia (2007) in olive oil $(\mathrm{RMSEP}=0.083 \%$ and $\mathrm{R} 2=0.99)$; once again, the difference between food matrixes must be taken into consideration. Although the $\mathrm{R}^{2}$ values were below 0.70 , considering the AI level of $0.5 \%$ as the maximum quality limit of macadamia nuts (SAMAC, 2015), the SEP value represented $28 \%$ of this limit. Consequently, the AI prediction as an analytical method can be considered acceptable as its total error was of the magnitude of $50 \%$ or less (McFarren, Lishka \& Parker, 1970).

The moisture prediction results (Table 3, Figure 4) indicate that the best calibration models for moisture content of unshelled nuts were obtained using $\mathrm{SG}+2 \mathrm{nd}$ derivative $\left(\mathrm{Rc}^{2}=0.66 ; \mathrm{RMSEc}\right.$ 
$291=2.33 \%$ ). Better results were reported by Guthrie, Greensill, Bowden \& Walsh (2005) who found 292 moisture content prediction models with RMSEcv of $0.11 \%$ and $\mathrm{Rc}^{2}$ of 0.79 . Their results were 293 improved by using ground nuts $\left(\mathrm{RMSEcv}=0.06 \% \mathrm{Rc}^{2}=0.95\right)$, and these differences could be due to 294 the lack of moisture homogeneity within our intact kernels; grinding should have reduced this 295 variation. Sumdaram, Kandala, Holser, Butts \& Windham. (2010) also reported better results for in 296 shell peanuts using NIRS $\left(\mathrm{RMSEp}=1.38 \%\right.$ and $\left.\mathrm{R}^{2} \mathrm{c}=0.98\right)$, but the moisture content range was 297 much higher (6.18 - 21.69\%) and should be taken into consideration.

298

\section{Conclusion}

Cultivars had little effect on the oxidative stability of intact unshelled macadamia nuts based on PV and AI. On the other hand, the drying process affected mostly the AI as the PV did not present any modifications during drying.

The NIR spectra were similar between cultivars, but the absorption bands changed during the drying process and the characteristic oil bands could be seen when the MSC, SNV, and SG smoothing derivatives were applied.

The PLS calibration models for PV and AI were considered useful since the error is lower of the quality limits. Therefore, NIRS can be used to assess the oxidative stability of intact macadamia nuts, but further investigation must be done to address other sources of variability to improve the robustness of the prediction models.

\section{Acknowledgment}

This study was financed in part by the Coordenação de Aperfeiçoamento de Pessoal de Nível Superior - Brazil (CAPES) - Finance Code 001.

\section{References}


317 Akinoso, R., Aboaba, S.A., \& Olayanju TMA. (2010). Effects of moisture content and heat treatment 318 on peroxide value and oxidative stability of un-refined sesame oil. African Journal of Food, 319 Agriculture, Nutrition and Development, 10, 4268-4285. Doi: 10.4314/ajfand.v10i10.62908 320 Ako, H., Okoda, D., \& Gray D (1995). Healthful new oil from macadamia nuts. Nutrition, 11, 286321288

322 Amodio, M.L., Ceglia, F., Chaudhrya, M.M.A., Piazzolla, F., \& Colellia G. (2017). Potential of NIR 323 spectroscopy for predicting internal quality and discriminating among strawberry fruits from 324 different production systems. Postharvest Biology and Technology, 125, 112-121. Doi: 325 10.1016/j.postharvbio.2016.11.013.

326 AOAC. (1997). Official methods of analysis of the association of official analytical chemists. (16th 327 ed.). Arlington: Patricia Cuniff.

328 Armenta, S., Garrigues, S., De la Guardia, M. (2007). Determination of edible oil parameters by near 329 infrared spectrometry. Analytica Chimica Acta, 596, 330-337. Doi: 10.1016/j.aca.2007.06.028 330 Arnett G. (1995). Macadamia oil. Australian Macadamia Society News Bulletin, 22: 23.

331 Bai, S.H., Darby, I., Nevenimo, T., Hannet, G., Hannet, D., Poienou, M., Grant, E., Brooks, P., 332 Walton, D., Bruce, R., \& Wallace HM. (2017). Effects of roasting on kernel peroxide value, free 333 fatty acid, fatty acid composition and crude protein content. Plos One, 12, 1-14. Doi: 334 10.1371/journal.pone.0184279

335 Barbosa, J.C., Maldonado Júnior, W. (2015). Experimentação agronômica \& Agroestat - Sistema 336 para análises estatísticas de ensaios agronômicos. Jaboticabal: Gráfica Multipress LTDA. 396 p

337 Bro, R., \& Smilde, A.K. (2014). Principal component analysis. Analitical Methods, 6, 2812-2831. Doi: 
339 Borompichaichartkul, C., Luengsode, K., Chinprahast, N., \& Devahastin, S. (2009) Improving 340 quality of macadamia nut (Macadamia integrifolia) through the use of hybrid drying process. 341 Journal of Food Engineering, 93, 348-353. Doi: 10.1016/j.jfoodeng.2009.01.035.

342 *Canneddu, G., Júnior, L.C., \& Teixeira, G.H.A. (2016). Quality evaluation of shelled and unshelled 343 macadamia nuts by means of near-infrared spectroscopy (NIR). Journal of Food Science, 81, 1613344 1621. Doi: 10.1111/1750-3841.13343.

345 Carvalho, L.C., Morais, C., Lima, K., Leite, G.W.P., Oliveira, G.S., Casagrande, I.P., Santos Neto, 346 J.P., \& Teixeira, G.H.A. (2018). Using intact nuts and near infrared spectroscopy to classify 347 macadamia cultivars. Food Analytical Methods, 11, 1857-1866. Doi: 10.1007/s 12161-017-1078-9

348 Cavaletto CG (1983). Macadamia nuts. In H.T.Jr. Chang (Ed.), Handbook of tropical foods, p.361397. New York: Marcel Dekker Inc.

*Cavaletto, C.G. (1981). Quality evaluation of macadamia nuts. In G. Charalambous., \& G. Inglett

(Eds.), Quality of foods and beverages: chemistry and technology, vol. 2 (pp. 71-82). New York: 352 Academic Press.

353 Cozzolino, D., Murray, I., Chree, A., \& Scaife, J.R. (2005). Multivariate determination of free fatty 354 acids and moisture in fish oils by partial least-squares regression and near-infrared spectroscopy. LWT, 38, 821-828. Doi: 10.1016/j.lwt.2004.10.007.

Cozzolino, D.; Cynkar, W.; Shah, N.; \& Smith, P.A. (2011) Can spectroscopy geographically classify Sauvignon blanc wines from Australia and New Zealand? Food Chemistry, 126, 673-678.

*Guthrie. J., Greensill, C., Bowden, R., \& Walsh, K. (2004). Assessement of quality defects in macadamia kernels using NIR spectroscopy. Australian Journal of agricultural Research, 55, 471476. Doi: 10.1071/AR03179. Doi: 0.1016/j.foodchem.2010.11.005.

Domínguez, I., Azuara, E., Vernon-Carter, E.J., Beristain, C.I. (2007). Thermodynamic analysis of the effect of water activity on the stability of macadamia nut. Journal of Food Engineering, 81, 566- 
*Kaijser, A., Dutta, P., \& Savage, G. (2000). Oxidative stability and lipid composition of macadamia nuts grown in New Zealand. Food Chemistry, 71, 67-70. Doi: 10.1016/S0308-8146(00)00132-1. Kennard RW, \& Stone LA (1969). Computer aided design of experiments. Technometrics, 11, 137148.

Mason, R.L. (2000). Macadamia nut quality research: the processing challenge. Food Australia, 52, 416-419.

370 Mason, R.L., \& Wills, R.B.H. (2000). Macadamia nut quality research: the processing challenge. $371 \quad$ Food Australia, 52, 416-419.

372 Mason, R.L., Nottingham, S.M, Reid, C.E, \& Gathambiri, C. (2004). The quality of macadamia 373 kernels stored in simulated bulk retail dispensers. Food Australia, 56, 133-139.

374 Mba, O., Adewale, P., Dumont, M.J., \& Ngadi, M. (2014). Application of near-infrared spectroscopy 375 to characterize binaryblends of palm and canola oils. Industrial Crops and Products, 61, 472-478. 376 Doi: 10.1016/j.indcrop.2014.07.037.

377 McConachie, I. (1996) Fats and oils as applied to macadamia nuts: a very basic chemistry lesson. 378 Australian Macadamia Society News Bulletin, 23, 34.

379 McFarren, E.F., Lishka, R.J., \& Parker, J.H. (1970). Criterion for judging acceptability of analytical 380 methods. Analytical Chemistry, 42, 358-365. Doi: 10.1021/ac60285a009.

*O'Hare P, Hidden DV, Burton D, Salmon T. (2004). Australian macadamia industry code of sound orchard practices. Australian Macadamia Society, Lismore.

Pankaew, P., Janjai, S., Nilnont, W., Phusampao, C., Bala, B.K. (2016). Moisture desorption 384 isotherm, diffusivity and finite element simulation of drying of macadamia nut (Macadamia 385 integrifolia). Food and Bioproducts Processing, 100, 16-24. doi.org/10.1016/j.fbp.2016.06.007

Pasquini, C. (2003). Near infrared spectroscopy: fundamentals, practical aspects and analytical applications. Journal of Brazilian Chemistry Society, 14, 198-219. Doi: 10.1590/s010350532003000200006. 
389 Ramalho, V.C., Jorge, N. (2006). Antioxidantes utilizados em óleos, gorduras e alimentos 390 gordurosos. Química Nova, 29, 755-760. Doi: 10.1590/S0100-40422006000400023

391 SAMAC - Southern African Macadamia Growers' Association. (2015). Raw macadamia products 392 quality specifications. http://www.samac.org.za/index.php/standards [Acessed January 2018].

393 Silva, F.A., Marsaioli, A.J., Maximo, G.J., Silva, M.A.A.P., Goncalves, L.A.G. (2005). Microwave 394 assisted drying of macadamia nuts. Journal of Food Engineering, 77, 550-558.

Silva, F.A., Maximo, G.J., Marsoioli, Junior, A., \& Silva, M.A.A.P. (2007) Impacto da secagem com microondas sobre o perfil sensorial de amêndoas de noz macadâmia. Ciência e Tecnologia de Alimentos, 27, 553-561.

Silva, F.A., Gonçalves, L.A.G., Damiani, C., Gonçalves, M.A.B., Soares Júnior, M.S., Marsaioli, 399 Júnior. A. (2011). Estabilidade oxidativa de amêndoas de noz macadâmia secas por micro-ondas com ar quente. Pesquisa Agropecuaria Tropical, 41, 286-292. Doi: 10.1590/S0101-20612007000300020.

Sinanoglou, V.J., Kakkotou, K., Fotakis, C., Strati, I., Proestos, C., \& Zoumpoulakis, P. (2014) Monitoring the quality of $\gamma$-irradiated macadamia nuts based on lipid profile analysis and Chemometrics. Traceability models of irradiated sample. Food Research International, 60, 38-47. beverage analysis (2nd ed.). Essex: Longman Group Burnt Mill, Harlow.

Wallace, H.M., \& Walton, D.A. (2011). Macadamia (Macadamia integrifolia, Macadamia tetraphylla and hybrids). In E.M. Yahia (Ed.), Postharvest biology and technology of tropical and subtropical fruits, vol. 3 (pp.450-473). Cambridge: Woodhead Publishing Series in Food Sciences, 
414 Wall, M.M (2013). Improving the quality and safety of macadamia nuts. In Harris, L.J. (Ed.), 415 Improving the quality and safety of nuts Cambridge: Woodhead Publishing Series in Food Science 416 Technology and Nutrition. 250: 274-296.

417 Wolff, J. P. (1997). Analysis and Determination of Lipids, In: Analysis of Food Constituents (pp. 418 175-220). Wiley - VCH Inc., Canada.

419 Wood, L.G., \& Garg, M.L. (2011). Macadamia nuts (Macadamia integrifolia and tetraphylla) and 420 their use in hypercholesterolemic subjects (pp.717-725). In: Preedy, V.R., Watson, R.R., Patel, V.B.

421 (ed.). Nuts \& seeds in health and disease prevention. Academic Press, London, UK.

422

423

*These references were fundamental for the discussion of the article, since they deal with 424 works similar to the above, using macadamia nuts, near infrared spectroscopy combined with 425 chemometrics and oxidative evaluation of nuts, clearly exposing the quality parameters of 426 macadamia nuts. 
430 Table 1. Descriptive statistics of unshelled macadamia nuts of the calibration and validation sets 431 obtained using the classic Kernnard-Stone selection algorithm.

\begin{tabular}{lccccc}
\hline Description & Total & Mean & Maximum & Minimum & SD $^{\mathbf{a}}$ \\
\hline Calibration set & $154^{*}$ & & & & \\
$\quad$ Peroxide value (meq.kg-1) & 154 & 0.90 & 5.41 & 0.12 & 0.82 \\
Acidity index (\%) & 154 & 0.68 & 2.26 & 0.20 & 0.35 \\
Validation set & $66^{*}$ & & & & \\
Peroxide value (meq.kg-1) & 66 & 0.86 & 2.49 & 0.14 & 0.58 \\
Acidity index (\%) & 66 & 0.60 & 1.65 & 0.18 & 0.30
\end{tabular}

$432{ }^{a} \mathrm{SD}=$ standard deviation. $*$ from the total of 240 samples, 20 were lost during oil extraction which 433 corresponds a total of 220 samples. 
438 Table 2. Moisture, dry matter, peroxide value, and acidity index of unshelled macadamia 439 (Macadamia integrifolia Maiden \& Betche) from different cultivars during drying process.

\begin{tabular}{lcccc}
\hline & $\begin{array}{c}\text { Moisture } \\
(\boldsymbol{\%})\end{array}$ & $\begin{array}{c}\text { Dry matter } \\
(\boldsymbol{\%})\end{array}$ & $\begin{array}{c}\text { Peroxide value } \\
\left(\mathbf{m e q . k g} \mathbf{- 1}^{-\mathbf{1}}\right.\end{array}$ & $\begin{array}{c}\text { Acidity ind } \\
(\boldsymbol{\%})\end{array}$ \\
\hline Harvests (B) & & & & \\
March & $7.2 \pm 3.7$ & $92.6 \pm 3.6$ & $1.15 \pm 1.05$ & $0.69 \pm 0.40$ \\
Aphril & $3.7 \pm 5.3$ & $94.4 \pm 3.7$ & $0.84 \pm 0.54$ & $0.66 \pm 0.28$ \\
May & $2.6 \pm 1.5$ & $97.4 \pm 1.5$ & $0.66 \pm 0.35$ & $0.61 \pm 0.32$
\end{tabular}

\section{Cultivars (C)}

$\begin{array}{lllll}\text { IAC } 412 & 7.1 \pm 7.9 & 92.8 \pm 7.9 & 1.08 \pm 0.67 & 0.72 \pm 0.37 \\ \text { IAC Campinas B } & 7.2 \pm 4.4 & 92.5 \pm 4.6 & 0.96 \pm 0.77 & 0.75 \pm 0.36 \\ \text { HAES } 660 & 6.4 \pm 5.5 & 93.9 \pm 5.4 & 0.90 \pm 0.54 & 0.67 \pm 0.22 \\ \text { HAES 344 } & 6.0 \pm 5.1 & 93.5 \pm 5.1 & 0.73 \pm 0.37 & 0.66 \pm 0.20\end{array}$

\section{Drying period (D)}

$\begin{array}{ccccc}0 & 13.8 \pm 6.9^{\mathrm{a}} & 86.2 \pm 6.4^{\mathrm{c}} & 1.27 \pm 0.97 & 1.01 \pm 0.43^{\mathrm{a}} \\ 4 & 6.1 \pm 2.7^{\mathrm{b}} & 93.3 \pm 3.1^{\mathrm{b}} & 0.93 \pm 0.61 & 0.63 \pm 0.27^{\mathrm{b}} \\ 6 & 4.1 \pm 1.5^{\mathrm{b}} & 95.9 \pm 1.5^{\mathrm{a}} & 0.81 \pm 0.36 & 0.61 \pm 0.12^{\mathrm{b}} \\ 7 & 2.6 \pm 1.2^{\mathrm{b}} & 97.4 \pm 1.2^{\mathrm{a}} & 0.66 \pm 0.27 & 0.56 \pm 0.21^{\mathrm{b}}\end{array}$

\section{Interaction}
C x D
NS
NS
NS
NS

Average values with the same letter in the columns are not statistically different by Tukey's test

$441(\mathrm{p}<0,05)$. Values in the column without letter are not statistically different by Tukey's test $(\mathrm{P}<0,05)$.

442 NS, non-significant interaction. 
446 Table 3. Statistical parameters for the optimal prediction models for peroxide value, acidity index, 447 and moisture of unshelled macadamia (Macadamia integrifolia Maiden \& Betche) from different 448 cultivars during drying process.

\begin{tabular}{|c|c|c|c|c|c|c|}
\hline \multirow{3}{*}{$\begin{array}{l}\text { Peroxide value (PV) } \\
\text { Pre-Processing }\end{array}$} & \multicolumn{6}{|c|}{ mequiv. $\mathrm{O}_{2} \mathrm{~kg}^{-1}$ units } \\
\hline & \multicolumn{2}{|c|}{ Calibration } & \multicolumn{4}{|c|}{ Validation } \\
\hline & $\mathrm{RMSE}_{\mathrm{c}}$ & $\mathrm{R}_{\mathrm{c}}^{2}$ & $\mathrm{RMSE}_{\mathrm{p}}$ & SEP & Bias & $\mathrm{RE}(\%)$ \\
\hline Raw & 0.78 & 0.18 & 0.47 & 0.42 & 0.21 & 66.57 \\
\hline $\mathrm{SG}+\mathrm{SNV}$ & 0.76 & 0.21 & 0.50 & 0.48 & 0.18 & 72.16 \\
\hline SG+MSC+baseline & 0.78 & 0.17 & 0.51 & 0.45 & 0.23 & 72.33 \\
\hline $\mathrm{SG}+2^{\text {nd }}$ derivative & 0.56 & 0.57 & 0.60 & 0.55 & 0.26 & 86.04 \\
\hline Acidity Index (AI) & \multicolumn{6}{|c|}{$\%(w / w)$ units } \\
\hline \multirow[t]{2}{*}{ Pre-Processing } & \multicolumn{2}{|c|}{ Calibration } & \multicolumn{4}{|c|}{ Validation } \\
\hline & $\mathrm{RMSE}_{\mathrm{c}}$ & $\mathrm{R}_{\mathrm{c}}^{2}$ & $\mathrm{RMSE}_{\mathrm{p}}$ & SEP & Bias & $\operatorname{RE}(\%)$ \\
\hline Raw & 0.36 & 0.06 & 0.22 & 0.16 & 0.15 & 38.89 \\
\hline $\mathrm{SG}+\mathrm{SNV}$ & 0.36 & 0.08 & 0.23 & 0.16 & 0.16 & 40.93 \\
\hline SG+MSC+baseline & 0.35 & 0.12 & 0.25 & 0.19 & 0.16 & 44.80 \\
\hline $\mathrm{SG}+2^{\text {nd }}$ derivative & 0.25 & 0.56 & 0.30 & 0.29 & 0.10 & 54.93 \\
\hline Moisture & & & w/w) unit & & & \\
\hline \multirow[t]{2}{*}{ Pre-Processing } & \multicolumn{2}{|c|}{ Calibration } & \multicolumn{4}{|c|}{ Validation } \\
\hline & $\mathrm{RMSE}_{\mathrm{c}}$ & $\mathrm{R}_{\mathrm{c}}{ }^{2}$ & $\mathrm{RMSE}_{\mathrm{p}}$ & SEP & Bias & $\operatorname{RE}(\%)$ \\
\hline Raw & 3.21 & 0.23 & 3.01 & 3.03 & 0.12 & 49.65 \\
\hline $\mathrm{SG}+\mathrm{SNV}$ & 3.22 & 0.23 & 3.12 & 3.15 & -0.01 & 51.51 \\
\hline SG+MSC+baseline & 3.26 & 0.21 & 3.20 & 3.23 & -0.15 & 52.83 \\
\hline $\mathrm{SG}+2^{\text {nd }}$ derivative & 2.13 & 0.66 & 3.23 & 3.26 & -0.07 & 53.31 \\
\hline Dry Matter & \multicolumn{6}{|c|}{$\%(w / w)$ units } \\
\hline \multirow{2}{*}{ Pre-Processing } & \multicolumn{2}{|c|}{ Calibration } & \multicolumn{4}{|c|}{ Validation } \\
\hline & $\mathrm{RMSE}_{\mathrm{c}}$ & $\mathrm{R}_{\mathrm{c}}{ }^{2}$ & $\mathrm{RMSE}_{\mathrm{p}}$ & SEP & Bias & $\mathrm{RE}(\%)$ \\
\hline Raw & 3.30 & 0.26 & 3.07 & 3.09 & -0.15 & 3.24 \\
\hline $\mathrm{SG}+\mathrm{SNV}$ & 3.30 & 0.25 & 3.17 & 3.20 & 0.01 & 3.34 \\
\hline SG+MSC+baseline & 3.34 & 0.24 & 3.26 & 3.28 & 0.15 & 3.43 \\
\hline $\mathrm{SG}+2^{\text {nd }}$ derivative & 2.19 & 0.67 & 3.31 & 3.33 & 0.01 & 3.48 \\
\hline \multicolumn{7}{|c|}{$\begin{array}{l}\text { mequiv = milliequivalent; } \mathrm{SG}=\text { Savitzky-Golay smoothing; } \mathrm{SNV}=\text { standard normal variate; } \mathrm{MSC}= \\
\text { multiplicative scatter correction; RMSEC }=\text { root mean square error of calibration; RMSEP }=\text { root } \\
\text { mean square error of prediction; } \mathrm{R}_{\mathrm{c}}{ }^{2}=\text { coefficient of determination for calibration; } \mathrm{SEP}=\text { standard }\end{array}$} \\
\hline
\end{tabular}


(A)

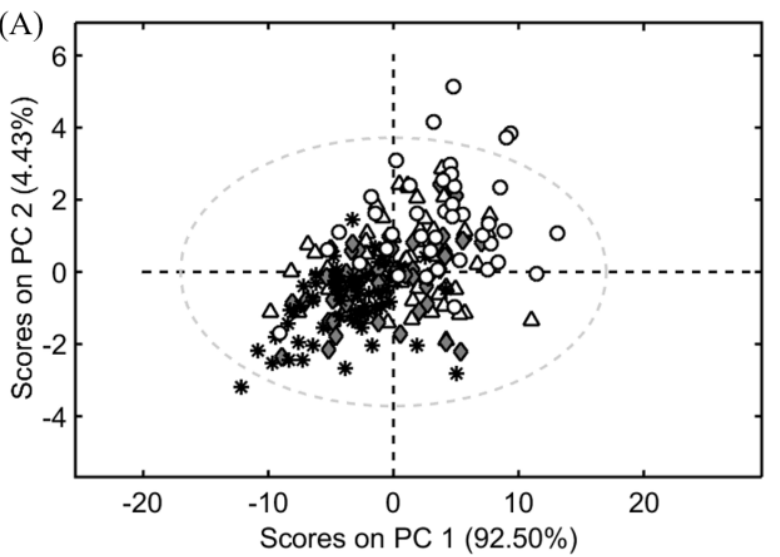

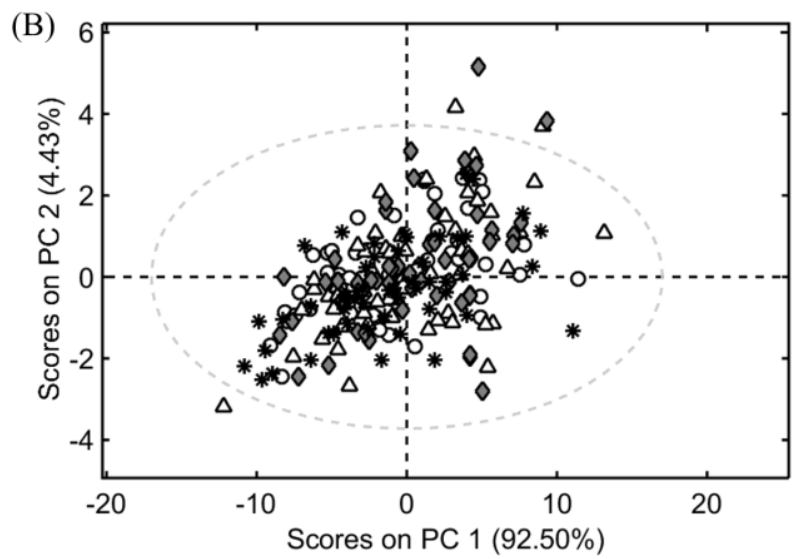

460 Figure 1. (A) scores of the PCA for the NIR spectra of drying process (Day 0 [०], 4 [ $\mathbf{\Delta}$ ], 6 [ $\diamond$, 7 $\left.461{ }^{*}\right]$ ); (B) scores of the PCA for the NIR spectra of unshelled macadamia (Macadamia integrifolia 462 Maiden \& Betche) nuts from different cultivars (IAC 4-12 [ $\diamond$ ], IAC Campinas B [*], HAES 660 [ $\mathbf{\Delta}$ ], 463 HAES 340 [०]). 

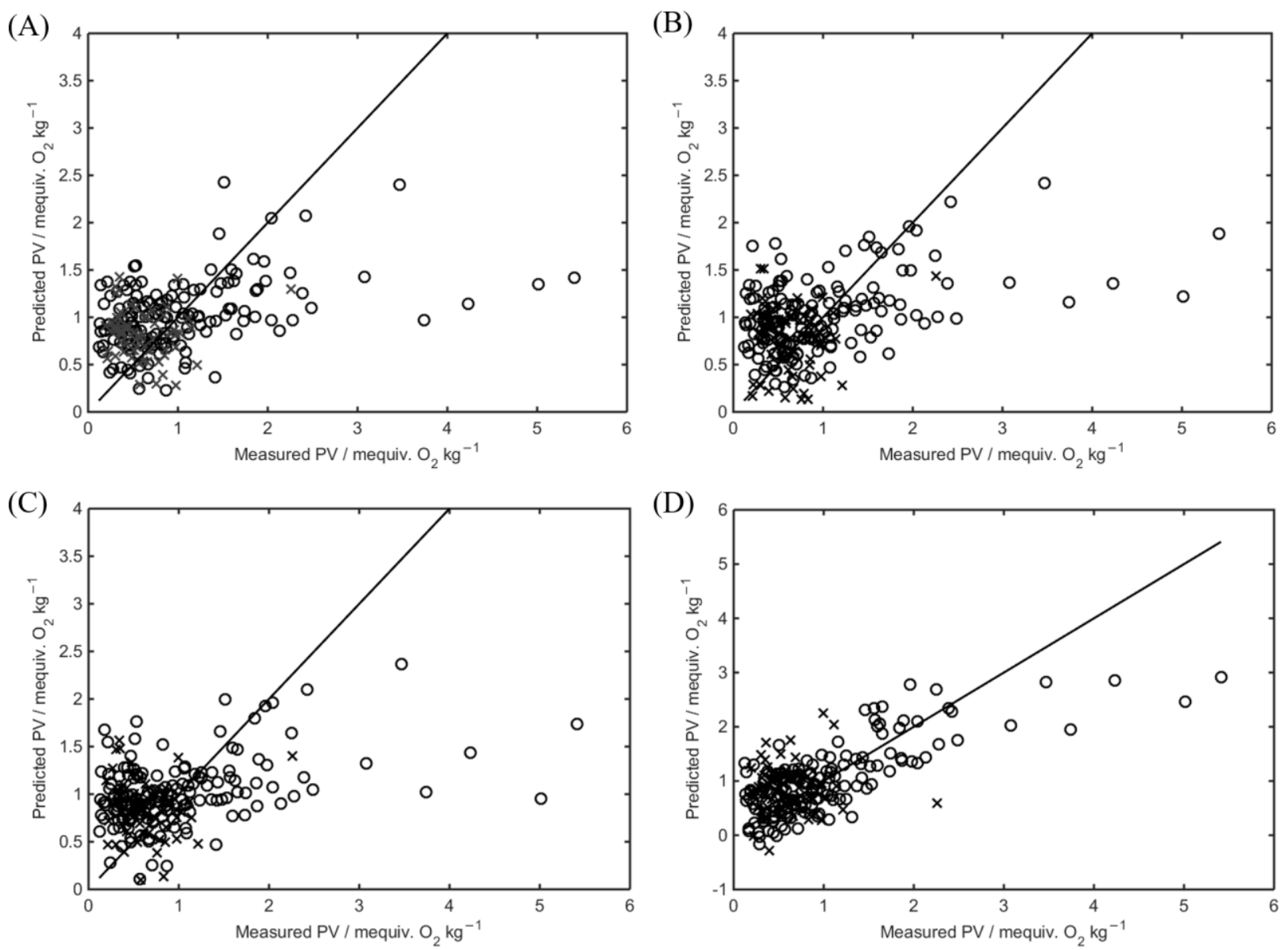

465 Figure 2. Measured versus predicted peroxide value (PV) for the calibration (o) and validation (x) 466 sets using PLS regression with the following pre-processing: (A) raw spectra; (B) SG+SNV; (C) 467 SG+MSC+baseline; (D) SG+2 ${ }^{\text {nd }}$ derivative. $\mathrm{SG}=$ Savitzky-Golay smoothing; $\mathrm{SNV}=$ standard 468 normal variate; $\mathrm{MSC}=$ multiplicative scatter correction 
(A)

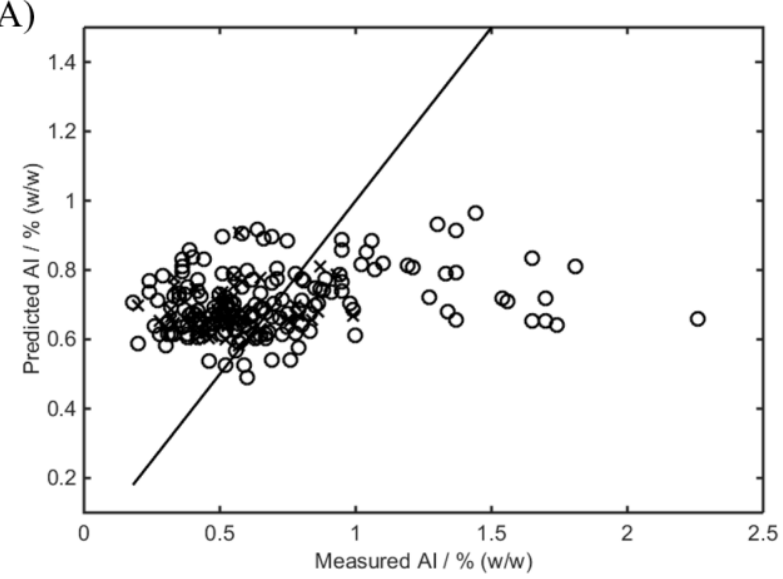

(C)

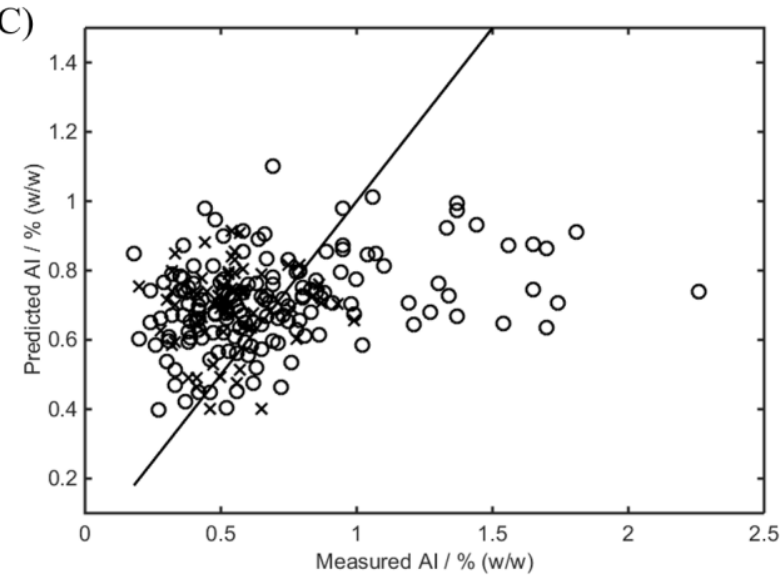

(B)

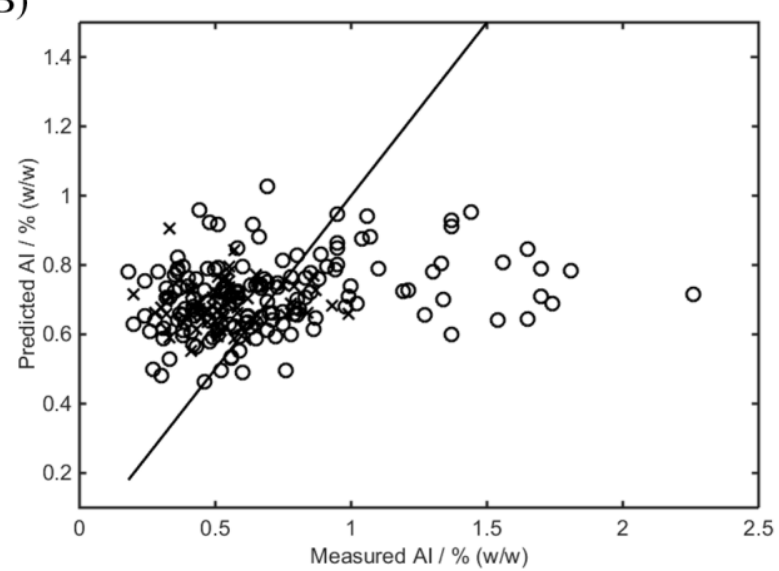

(D)

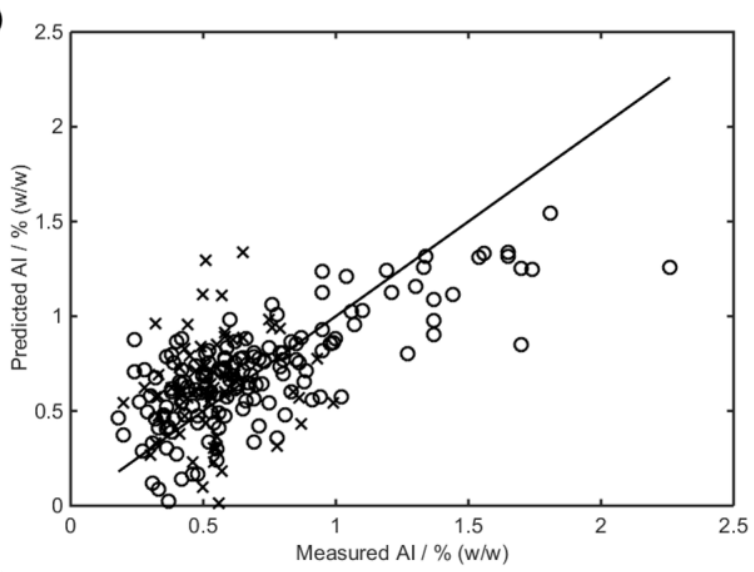

470 Figure 3. Measured versus predicted acidity index (AI) for the calibration (o) and validation (x) sets 471 using PLS regression with the following pre-processing: (A) raw spectra; (B) SG+SNV; (C) 472 SG+MSC+baseline; (D) $\mathrm{SG}+2^{\text {nd }}$ derivative. $\mathrm{SG}=$ Savitzky-Golay smoothing; $\mathrm{SNV}=$ standard 473 normal variate; $\mathrm{MSC}=$ multiplicative scatter correction 

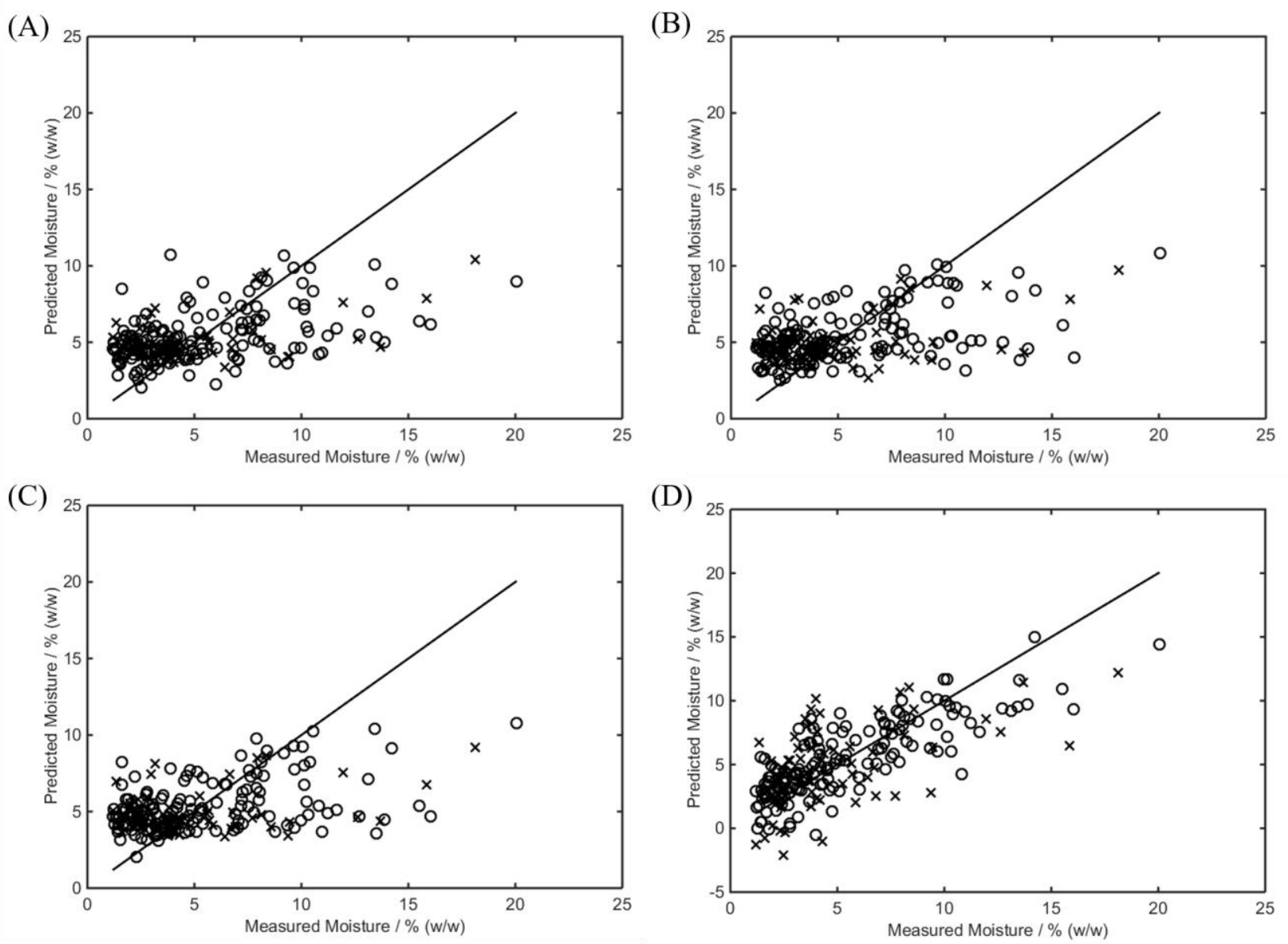

475 Figure 4. Measured versus predicted moisture for the calibration (o) and validation (x) sets using 476 PLS regression with the following pre-processing: (A) raw spectra; (B) SG+SNV;

477 SG+MSC+baseline; (D) SG+2 ${ }^{\text {nd }}$ derivative. $\mathrm{SG}=$ Savitzky-Golay smoothing; SNV = standard 478 normal variate; $\mathrm{MSC}=$ multiplicative scatter correction. 